\title{
SELECTION OF RED MOTLEY HOLSTEIN BULLS BY GENOTYPE AND THEIR EXTENSIVE USE IN BREEDING
}

\author{
Mukhayyo Khusnitdinovna \\ Dosmukhamedova \\ Doctor of Agricultural Sciences, \\ Professor of the Department of General \\ Zootechnics, \\ Tashkent State Agrarian University, \\ Tashkent, \\ Uzbekistan
}

\author{
Olim Eshonkulovich Mamatkulov \\ Independent Researcher, \\ Department of General Zootechnics, \\ Tashkent State Agrarian University, \\ Tashkent, \\ Uzbekistan
}

Article DOI: https://doi.org/10.36713/epra4517

\begin{abstract}
The article describes the selection of red motley Holstein bulls by genotype imported from Germany to the state enterprise "Uznaslchilik" and their use in breeding practices, which are also characterized by breeding and productivity qualities typical of black motley types. In the study of world breeding practices, new high-yielding herds are being formed by crossing dairy red breeds with red motley Holstein breed bull-improvers. The red motley Holstein breed is also recognized in our country as an improver and is being used in artificial insemination.
\end{abstract}

KEYWORDS: Red motley Holstein breed, breeding and productivity, artificial insemination, crossbreeding, selection and pairing, fertile, individual, genotype, breeding, total merit index, farm useful traits.

\section{INTRODUCTION}

New stage of intensive development of animal husbandry and mainly, cattle breeding has begun in Uzbekistan. An example of this is the establishment of the agency "Uzbekchorvanasl" by the decree of the President of the Republic of Uzbekistan Shavkat Mirziyoyev, from March 28, 2019 numbered PD-4654, and this kind of measures on the rapid development of animal husbandry is expected to be effective within a short time. In particular, huge changes are expected to happen in cattle breeding. In cattle breeding the breeds and herds get improved over the time and their breeding base is also formed and improved respectively. In this regard, the improvement of red colour herds is of particular importance. Because, a number of red dairy breeds ranks the second after black motley Holstein breeds in the farms of the republic. They have been regionized for crossing in the farms of southern regions of the republic and the Republic of Karakalpakstan. The use of modern methods of selection and application of breeding work is relevant in improving herds and strengthening their breeding base. First of all, it is important to choose improving breeds and bull- improvers. It is known from the experience of the world breeding that at present all red dairy breeds are being improved by crossing with red motley Holstein breeds, and new productive herds and breeds are being formed. In Uzbekistan, a red motley Holstein breed is recognized as an improver breed, and is used extensively $[1 ; 2]$.

In this regard, the selection of red motley Holstein bull-improvers and the extensive use of their sperm in the breeding work and artificial insemination methods show their breeding effectiveness.

Red motley Holstein breed cattle have breeding and productivity qualities typical of black motley types. On the basis of breeding work on bulls and cows, their individual selection and pairing, the generation of genetic breeding and productivity potential is being obtained. As a result, the milk yield of cows in breeding herds has increased by 9-10 thousand kilograms, and their mothers' by $25-30$ thousand kilograms [3; 4].

In the USA, Canada, Germany and Holland, the breeding bases of red motley Holstein breed cattle are getting improved. Besides, bulls and heifers are being exported to other countries. Since 2000, red motley bulls of Holstein breed have been imported to 
Uzbekistan, and are used in artificial insemination widely. In farms of Khorezm region, the generations from red motley Holstein and red steppe breed cattle has been achieved. At the present time, these practices are performed widely. Crossing of red steppe breed cows of Angler genotype with red motley bull-improvers of Holstein breed is showing its effectiveness in practice. New generations gained are characterized with their breeding and productivity traits $[5,6,7]$.

\section{MATERIALS AND METHODS}

Genotype evaluation and selection of red motley bull-improvers of Holstein breed imported from abroad is being paid attention to widely. On the base of modern selection, breeding methods have been used properly. Experiments were carried out in "Uznaslchilik" state enterprise in Kibray district of Tashkent region during the years 2018-2020.

A total merit index of bull genotype (RZG) and official index for production (RZM), conformation traits (RZE), somatic cell score (RZS), fertility (RZN) and farm use (RZR) indexes were estimated based on the analysis of each bull's passport.

\section{RESULTS AND DISCUSSION}

It should be noted that the red motley Holstein breed cattle has better adaptation to hot climates and dry weather than the black motley type cattle.

Therefore, we selected red motley bull-improvers of Holstein breed from Germany by their genotype. In Germany, selection work has been organized on the genotype of red motley Holstein pedigree cattle, i.e on the ancestral genus and quality of generation, and also high-genotype and productive generations have been gained in improving its priority, the breeding base is being strengthened respectively.

\section{Table}

Formation of sire breeding index of imported pedigree bulls and farm useful indexes of their generation

\begin{tabular}{|c|c|c|c|c|c|c|c|c|}
\hline \multirow[b]{2}{*}{ № } & \multicolumn{2}{|c|}{ Breeding bulls } & \multirow[b]{2}{*}{$\begin{array}{l}\text { Total merit } \\
\text { index of } \\
\text { genotype } \\
\text { (RZG) }\end{array}$} & \multicolumn{5}{|c|}{ Formation of farm useful indexes of sire generation } \\
\hline & Name & Number & & $\begin{array}{c}\text { Official } \\
\text { index for } \\
\text { productio } \\
\text { n (RZM) }\end{array}$ & $\begin{array}{c}\text { Conform } \\
\text { ation } \\
\text { traits } \\
\text { index } \\
\text { (RZE) }\end{array}$ & $\begin{array}{c}\text { Somatic } \\
\text { cell score } \\
\text { (RZS) }\end{array}$ & $\begin{array}{c}\text { Fertility } \\
\text { index } \\
\text { (RZN) }\end{array}$ & $\begin{array}{c}\text { Farm use } \\
\text { index } \\
\text { (RZR) }\end{array}$ \\
\hline \multicolumn{9}{|c|}{ Bull-improvers } \\
\hline 1 & Wola & 22398778 & 127 & 118 & 120 & 101 & 117 & 108 \\
\hline 2 & Pepe & 22446925 & 131 & 121 & 136 & 101 & 109 & 107 \\
\hline 3 & Uptonu & 22446938 & 130 & 118 & 129 & 107 & 116 & 105 \\
\hline 4 & Unno & 22379529 & 136 & 131 & 122 & 104 & 113 & 104 \\
\hline 5 & Usamo & 22446938 & 137 & 136 & 116 & 110 & 113 & 93 \\
\hline \multicolumn{3}{|c|}{ Mean: } & 132,2 & 124,8 & 124,6 & 104,6 & 113,6 & 103,4 \\
\hline \multicolumn{9}{|c|}{ Leading bull-improvers } \\
\hline 1 & Unven & 22379537 & 139 & 130 & 130 & 108 & 116 & 108 \\
\hline 2 & Untamo & 22379532 & 143 & 144 & 116 & 114 & 113 & 90 \\
\hline 3 & Upke & 22446906 & 143 & 144 & 116 & 114 & 113 & 90 \\
\hline 4 & Unni & 22379520 & 147 & 135 & 132 & 119 & 116 & 112 \\
\hline 5 & Upendu & 22398786 & 147 & 135 & 132 & 119 & 116 & 112 \\
\hline 6 & Upenda & 22398783 & 147 & 135 & 132 & 119 & 116 & 112 \\
\hline \multicolumn{3}{|c|}{ Mean: } & 144,3 & 137,2 & 126,3 & 115,5 & 115,0 & 104,0 \\
\hline
\end{tabular}

Imported breeding bulls with these indexes are being bred in "Uznaslchilik" state enterprise and their sperm bank has been prepared. According to the plan of breed regionizing, selection methods are applied. Individual breeding and productivity traits of bulls selected genetically and typical of high breeding genotype are presented in the following table by their genotype.

The table data shows that the red motley bullimprovers of Holstein breed were obtained from bulls of high-breeding genotype. Their parental ancestors were selected on the basis of individual ordered selection, and quality indicators of their generation. Their total merit (sire) index made average 132.2 and 144.3, respectively for the selected bull groups. They own very high breeding tendency.

Their total merit (sire) index ranged from 127 to 147. For the rise of total merit index, it was observed that the farm useful indexes of sire generation were formed at different levels. While the milk productivity of generation has risen sharply, the various conformation traits index and fertility indexes also have a rising character. The indexes of farm use time of breeding and productive cattle made 103-104\% remaining without changes. That is, the parameters of this index are much higher than the standards of red motley cattle of Holstein breed. In this case, the herds will improve over time. 
It is known that the red steppe cows bred in the Republic are smaller and have less milk capacity than the black motley breeds, while the generation obtained from crossbreeding with the red motley Holstein breed is not inferior to them. That is, selection for crossbreeding manifested a high level efficacy. Highyielding herds and breeding bases of red motley new generations of Holstein genotype of the red steppe breed are formed. In this regard, the hereditary influence of the leader bull-improvers gives its positive result. It is obvious from the practice of republican farms that in $95 \%$ crossbreeding of cattle at public and peasant farms and only $5 \%$ at farms the sperm of bulls with high genetic breeding qualities is used widely in artificial insemination and therefore the herds are improved rapidly. Selected red motley Holstein bulls not only serve to improve the breeding base of the Republic, but also they are characterized by expert qualities. These include the bulls with a total merit index of $140-147 \%$. If milk productivity index of generation rises to $135-147$ $\%$, body structure conformation index gets improved by $130-132 \%$ than standard breed. Fertility of cows and bacterial storage properties increase to $115-119 \%$. Fertility and farm use time index is kept at high level. Currently, there is a plan to combine red motley Holstein breed bull-improvers with red steppe cattle for artificial insemination, and their sperm is being sent to farms in the southern regions. In Khorezm and Bukhara regions, measures are being taken to select control farms and to use them for breeding and evaluating new generations. In the future, these control farms will be used to evaluate and select bulls on generation quality. Strategies for the rapid development of cattle, improving their breeding and productivity qualities are expected to give yielding positive results in a short time.

\section{CONCLUSION}

1. In the improvement of red steppe cattle bred in the southern regions of the country and the Republic of Karakalpakstan, the red motley Holstein breed is regarded as a breed-improver and is used by farms.

2. Red motley Holstein bull-improvers have been selected for extensive use in crossbreeding and artificial insemination, and their sperm bank reserves have been created.

3. High-yielding generations are obtained from red motley bull-improvers of Holstein breed, and their herds are formed. The breeding base will be strengthened accordingly.

4. Bull-improvers and especially, leading bullimprovers are characterized by high genetic breeding and productivity indicators. Their use leads to effective breeding work and economical effectiveness.

\section{REFERENCES}

1. Decree of the President of the Republic of Uzbekistan numbered PD-4254 from March 28, 2019 "About the organization of the activity of State Committee of Veterinary and Livestock development of the Republic of Uzbekistan".

2. Decree of the President of the Republic of Uzbekistan numbered PD-4947 from 2017, "About the strategy of actions" on five priority lines of further development of the Republic of Uzbekistan during the years 2017-2021.

3. Nosirov U.N. et al. (2008). Classic and modern selection methods. Tashkent.

4. Nosirov U.N., Maksudov I., Dosmukhamedova M.Kh. (2011). Development factors of cattle breeding in Uzbekistan. Tashkent, SML-ASIA. 195 p.

5. Dosmukhamedova M.Kh., Nosirov U.N., Shakirov K.J., Mamurov G., Esanov A. (2019). Selection of imported black-motley bulls - improvers of Holstein breed and their efficient usage in improvement of black-motley strain herds. EPRA International Journal of Research Development (IJRD), Vol., 4, Iss. 5, pp. 97-99.

6. Dosmukhamedova M.Kh., Nosirov U.N., Khodjayev U., Mavlonov Sh. (2019). Selection and evaluation on the father ancestors genotype and mother ancestors productive indices of imported fleckvieh simmental and schwyz breed combined-productive improver bulls. International Journal of Advanced Research (IJAR). Vol. 7, Iss. 5. pp. 321-324.

7. Mamatkulov O., Dosmukhamedova M.Kh., Nosirov U.N. (2019). Selection of imported bulls of Redmotley Holstein and Angler breeds, and also red strain of dairy direction herds' improvement in the artificial insemination system // International journal for innovative research in multidisciplinary field. Vol. 5, lss. 5., pp. 205-207.

8. Mamatkulov O., Nosirov U.N, Dosmukhamedova M.Kh. (2019). The use of strains of red motley Holstein breed and Angler breed bulls in the improvement of dairy red breeds. "Livestock and breeding work”. J. № 05 (10). pp.14-15. 